Research article

\title{
Spatiotemporal analysis of the impact of artificial beach structures on biogeomorphological processes in an arid beach-dune system
}

\author{
Abel Sanromualdo-Collado *, Leví García-Romero, Carolina Peña-Alonso, \\ Antonio I. Hernández-Cordero, Nicolás Ferrer-Valero, Luis Hernández-Calvento \\ Grupo de Geografía Física y Medio Ambiente, Instituto de Oceanografía y Cambio Global, Universidad de Las Palmas de Gran Canaria, Unidad Asociada ULPGC-CSIC, \\ Spain
}

\section{A R T I C L E I N F O}

\section{Keywords:}

Deflation surfaces

Geomorphological resilience

Environmental impacts

Tourism pressure

Coastal aeolian sedimentary systems

\begin{abstract}
A B S T R A C T
The research hypothesis considered in this study is that decisions adopted on beach use and management in arid environments can result in significant changes in the biogeomorphological processes of the beach-dune system of which it forms part. Different information sources and geographical information systems were used to make a spatiotemporal analysis of possible correlations between the presence of beach equipment, services and uses in the backshore area of an arid beach-dune system, such as the beach named Playa del Inglés (Gran Canaria island, Spain) and environmental changes detected in the same area. The period considered in the study covers from 1961 (before the development of the mass tourism on the island) to 2018. Significant variations in vegetation cover over the course of the study period were detected, as well as an overall increase in erosion (topographic and erosive aeolian landforms) and foredune fragmentation and a decrease in geomorphological resilience. The study found not only relationships between management decisions and environmental impacts, but also that environmental impacts of management decisions on beach use made in the 1970s and 1980s continue to be felt today. Moreover, the results also reinforce the idea that management decisions made based on the results of scientific research studies (management-research binomial) can lead to more environmentally sustainable actions.
\end{abstract}

\section{Introduction}

Coastal dunes are extremely important in socio-ecological terms given the wide range of ecosystem services that they provide (Barbier et al., 2011; Everard et al., 2010; Miththapala, 2008). There has been growing interest in recent decades in the aesthetic and recreational value of these spaces, particularly in view of their frequent use as areas of leisure and relaxation (Ministerio de Medio Ambiente y Medio Rural y Marino, 2008).

The conversion of dune systems into priority spaces for tourism has intensified urbanization processes in the surrounding areas. In turn, this has resulted in environmental alterations that have contributed to the degradation of these dune systems and, in some cases, have brought about the destruction of the ecosystems that they are part of, something that it has been possible to identify in numerous European dune fields (European Environment Agency, 2006; Paskoff, 1993). Functional imbalances have arisen in many dune systems, offering a clear example of the conflict between development and conservation (Nordstrom et al., 2000). The manifestations of these processes may have their origin in the anthropic occupation of water basins or littoral zones that feed the dune systems with sand (Del Río and Malvárez, 2017), in their direct occupation, in dumping, or in the extraction of aggregates, among many others (De Andrés Díaz and Gracia Prieto, 2002). Commonly, one of the key components to the proper functioning of the systems as a whole, the foredune, shows a high degree of sensitivity to anthropic-sourced alteration processes (Bauer and Sherman, 1999). In order to understand the processes in these systems as a whole, spatiotemporal information that reveals behavioural patterns of foredunes and dunefields is required (Livingstone et al., 2007). For this, the use of historical information sources is necessary, especially aerial photography and satellite imagery (Livingstone et al., 2007; Hugenholtz et al., 2012; Cham et al., 2020).

The so-called climatic comfort concept (Gómez Martín, 2005) has been a fundamental aspect in the development of tourism, to the extent

\footnotetext{
* Corresponding author.

E-mail addresses: abel.sanromualdo@ulpgc.es (A. Sanromualdo-Collado), levi.garcia@ulpgc.es (L. García-Romero), carolina.pena@ulpgc.es (C. Peña-Alonso), hernandez.cordero@ulpgc.es (A.I. Hernández-Cordero), Nicolas.fvg@ulpgc.es (N. Ferrer-Valero), luis.hernandez.calvento@ulpgc.es (L. Hernández-Calvento).
} 
that it has conditioned the demarcation of spaces for tourist activities at regional and global scales. Warm and temperate areas (as is the case of the coastal areas of the Canary Islands) are considered optimal for the development of what is known as sun and beach tourism (Burton, 1991; Lozato-Giotart and Insa, 1990; Soneiro-Callizo, 1991; Vera Rebollo, 1997). Unlike other European tourist destinations, the climate of the Canary coasts is stable almost all year round, with mild temperatures, little rainfall, and many hours of sunshine. Mass tourism, a year-round occurrence in the islands with two visitor peaks unlike most other European tourist destinations (Cabrera-Vega et al., 2013a), has in many areas of the islands resulted in a drastic urban over-occupation of littoral areas and, as in other territories, coastal degradation (European Environment Agency, 2006).

Several studies have analysed the impact of human activities, including traditional ones such as grazing, firewood collection and agriculture, on the dune systems of the Canary Islands (Marrero-Rodríguez et al., 2020; Santana-Cordero et al., 2016). Some studies have also considered the impact of more recent land use changes, often carried out with non-existent or inadequately developed environmental planning and management, that have allowed aggregate extraction or given rise to the development of recreational and tourism infrastructures and urbanizations in the immediate surroundings of these systems and occasionally even occupying them (Ferrer-Valero et al., 2017; Hernández-Calvento, 2006; Santana-Cordero et al., 2014). Mass tourism has played a major role in the development of impacts that directly or indirectly affect geomorphological and ecological elements of beach-dune systems of the islands (Peña-Alonso et al., 2018). These impacts include changes to foredune morphology (including their disappearance in some sectors) as a result of alterations to the vegetation (Hernández-Cordero et al., 2012, 2017; Viera-Pérez et al., 2019), occupation by buildings and equipment (García-Romero et al., 2016), and alterations to aeolian sedimentary dynamics due to changes in wind intensity and directions caused by buildings and beach equipment (García-Romero et al., 2019a; Hernández-Calvento et al., 2014; Smith et al., 2017). The foredune and its associated vegetation play an extremely important functional role in dune systems as they regulate sediment transport to the interior of the system and supply the beach with sediments when it is eroded by the actions of the sea (Bauer and Sherman, 1999; Hesp, 2002). Deterioration of the foredune has two main consequences. The first involves a decrease in the geo-ecological effects of the coastal dune in the context of the dune systems in which they are integrated. The second is a socioeconomic impact related to the degradation of the characteristic landscape of these areas and, in consequence, their decreased attraction for tourism and recreation.

The decisions that are taken in terms of their use and management can be determining factors in preserving aeolian sedimentary dynamics and the morphological and functional structure of any dune system, and in particular the foredune area (Jackson and Nordstrom, 2011). For example, the presence of beach equipment can alter the erosion-sedimentation pattern towards the interior of the system, as the flow around barriers is speeded up and zones are generated where sediment transport is increased and local erosion phenomena are created (Jackson and Nordstrom, 2011; Nordstrom, 2000; Poppema et al., 2019). In this respect, on Playa del Inglés beach (Maspalomas, Gran Canaria), the interference of permanent beach equipment (kiosks and sunbeds) and certain beach user activities led to the formation of wind shade corridors and deflation surfaces that extended from the back beach to the foredune area (Hernández-Calvento, 2002; Instituto Tecnológico Geominero de España, 1990; Martínez, 1990). These erosive landforms developed despite some of the barriers being removed years earlier (Díaz Guelmes and Hernández-Calvento, 2004). Subsequent studies also revealed the loss of vegetation to be a factor in foredune alteration (Hernández-Cordero et al., 2012, 2018; Pérez-Chacón et al., 2007).

Along this line, the aim of the present study is to consider in greater depth the relationship between beach management/use and the alterations to the biogeomorphological elements of the beach-dune system of this particular beach, Playa del Inglés, that have taken place in parallel with the tourism development process from the 1960s to the present day. Although there are related studies conducted in temperate environments (Nordstrom et al., 2007; Martínez et al., 2013; Corbau et al., 2015) as well as in arid environments with low human pressure (Amini et al., 2011), the innovation of this research is especially significant due to the specific characteristics of the study area: a fragile arid coastal environment with low plant cover, with a naturally fragmented foredune and subjected to an intensive tourist pressure along the whole year (Garcia-Romero et al., 2021), where the biogeomorphological processes are rapidly changing. The hypothesis considered in this study is that the decisions that have been adopted on the use and management of Playa del Inglés have induced changes in the aeolian sedimentary dynamics of the beach-dune system that have had significant repercussions on the dimensions, structure and functionality of the foredune. For this purpose, an analysis is undertaken of the correlations between, on the one hand, the presence of beach equipment, services offered and activities undertaken on the backshore of the beach and, on the other, the biogeomorphological transformations that took place in the period between 1961 and 2018. Based on this analysis, an evaluation is then made of how the land use and management measures adopted by administrations can affect and compromise the conservation of coastal dune systems. In the next section, a description of the study area is introduced. In the third section, the information sources and the methodology are described in detail. In the fourth section, the main results about the evolution of biogeomorphological elements and their relationships with beach equipment are presented and widely discussed. Finally, the conclusions are gathered in the fifth section.

\section{Study area}

The Maspalomas dunefield $\left(27^{\circ} 44^{\prime} 24.73^{\prime \prime} \mathrm{N} ; 15^{\circ} 34^{\prime} 26.19^{\prime \prime} \mathrm{W}\right)$ is a 360.9 ha transgressive arid dune system situated on the south coast of the island of Gran Canaria (Fig. 1). It was declared a Special Nature Reserve by the Canary Regional Government and a Special Area of Conservation (SAC) by the EU. Beaches are not included in these protected areas.

Mean annual rainfall in the dunefield is less than $100 \mathrm{~mm}$ and mean annual temperature is $21^{\circ} \mathrm{C}$, with only slight variation throughout the year (Hernández-Cordero et al., 2019). The effective prevailing winds are NE, ENE and E, favouring sedimentary transport (FMáyer Suárez et al., 2012). In consequence, the dunes move from NE to SW, from their access to the system through Playa del Inglés. The foredune is situated on the backshore, comprised of nebkhas, shadow-dunes and tongue dunes (parabolic-shaped, unvegetated, arcuate ridges) (Viera-Pérez, 2015) which are formed by colonization of the plant species Traganum moquinii (Hernández-Cordero et al., 2012). This shrub species contributes to the accumulation of sand, favouring the formation of nebkhas which regulate the transport of sediment to the interior of the dunefield. In between these nebkhas, tongue dunes are formed which evolve into barchan dunes as they advance towards the interior of the system (Cabrera-Vega et al., 2013b; Domínguez-Brito et al., 2020; Hernández-Cordero et al., 2012).

Playa del Inglés is a space with year-round intensive tourism use. In the northern half of the beach the density of equipment such as kiosks, parasols and sunbeds is high, while other equipment for the rental of small recreational watercrafts can be found in the most elevated section of the profile protected from tidal effects. In the southern half, from the backshore to the interior of the system, an abundant number of windbreak structures, locally known as goros, can be found. These circular structures, constructed by beach users with large pebbles for protection against wind and sand, can generate impacts at local scale by modifying aeolian transport and damaging T. moquinii specimens, behind which the goros tend to be constructed.

The 71.6 ha study area extends, from east to west, from Playa del 
$A$
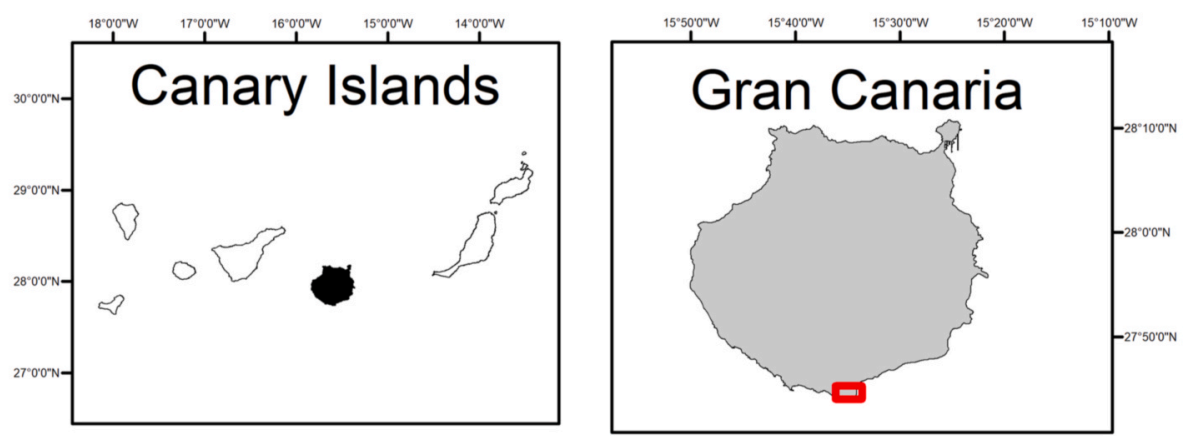

Maspalomas Dunefield

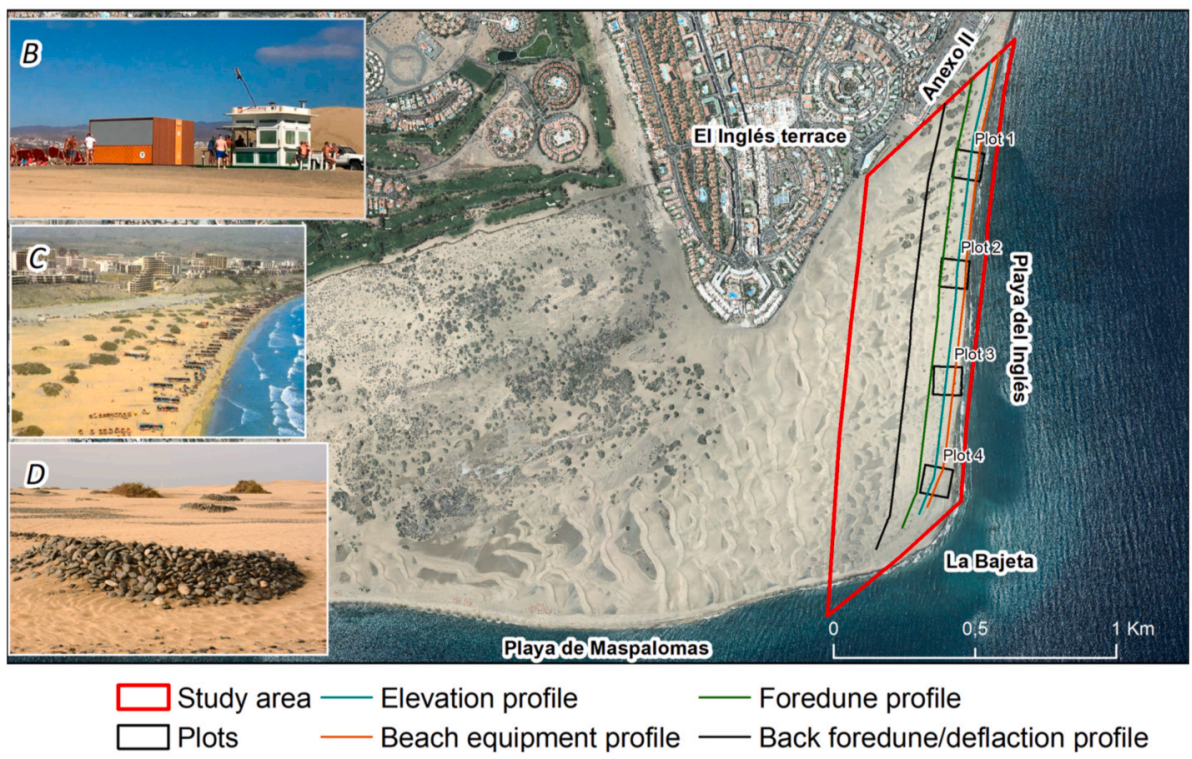

Fig. 1. A) Study area, profiles used to analyse the variables studied in this work and plots established for the geomorphological resilience study. Source of orthophoto: IDECanarias, GRAFCAN, S.A.-Canary Islands Government (2018). Coordinates UTM. Zone 28 N. Ellipsoid WGS 84. Datum REGCAN95. B) Kiosk type until 2019 (white on the right) and new kiosk from 2019 (orange on the left) (source: Canarias7 newspaper). C) Kiosk and sunbed distribution in the 1970s. D) Goro (artificial windbreak structure) and examples of T. moquinii (Source: Masdunas project). (For interpretation of the references to colour in this figure legend, the reader is referred to the Web version of this article.)
Inglés towards the interior of the system and, from north to south, from the Anexo II shopping centre towards the tip of La Bajeta. The northern area of the beach, where some human impacts have previously been studied in detail (Hernández-Cordero et al., 2017; Peña-Alonso et al., 2018; Viera-Pérez et al., 2019) has been excluded from the study, as much of its surface was built on towards the end of the 1980s and so it is not possible to analyse the biogeomorphological evolution of the foredune. For the purposes of this study, four $100 \times 100 \mathrm{~m}$ plots, separated from each other by an approximate distance of $400 \mathrm{~m}$ along the N-S profile of the beach (see Fig. 1) were established and used for an analysis of geomorphological resistance.

\section{Methodology}

A decade-based analysis was carried out of the spatiotemporal correlations between the geomorphological transformations of the foredune and its immediate surroundings and the presence and distribution of beach equipment (mainly kiosks and groups of sunbeds) and goros (Fig. 1D). The years of the study period selected for this analysis were 1961 (before the development of tourism in the area), 1977, 1987, 1998, 2006 and 2018. The information used (Table 1) was collected mainly from historical aerial photographs, digital orthophotos and digital elevation models derived from LiDAR flights, using the maximum resolution of each information source and geographic information systems (GIS). Fieldwork was also undertaken for the more recent dates. The WGS84-UTM 28-N reference system was used. The delineation error was calculated according to Robinson et al. (1987).
Table 1

Characteristics of the information sources used.

\begin{tabular}{|c|c|c|c|c|}
\hline Type (source) & Year & $\begin{array}{l}\text { Spatial } \\
\text { resolution (m) }\end{array}$ & Use & $\begin{array}{l}\text { Delineation } \\
\text { error (m) }\end{array}$ \\
\hline \multirow[t]{2}{*}{$\begin{array}{l}\text { Historical aerial } \\
\text { photographs (1, } \\
\text { 2) }\end{array}$} & $\begin{array}{l}1961 \text { (RMS: ) } \\
\text { web map } \\
\text { service }\end{array}$ & 0.12 & * & 0.12 \\
\hline & $\begin{array}{l}1977(1: 6500) \\
\text { (RMS: } 1.54 \mathrm{~m})\end{array}$ & 0.9 & & 1.3 \\
\hline $\begin{array}{l}\text { Orthophotos (1, 2, } \\
\text { 3) }\end{array}$ & $\begin{array}{l}\text { 1987, 1998, } \\
2006,2018\end{array}$ & $\begin{array}{l}0.15,0.25 \\
\text { and } 1\end{array}$ & * & $0.15,-, 1$ \\
\hline DEMs $(1,2,4)$ & $\begin{array}{l}10 / 2006,03 / \\
2011,11 / 2018\end{array}$ & 1 & a & a \\
\hline
\end{tabular}

(1) IDECanarias, GRAFCAN, S.A.-Canary Islands Government (web map service or LiDAR flights); (2) Grupo de Geografía Física y Medio Ambiente (IOCAG, ULPGC); (3) Instituto Geográfico Nacional (IGN); (4) LiDAR flights (file.las) (2006, 2011, 2018). *eco-anthropogenic variables;

${ }^{a}$ elevation profile; - missing data.

From these information sources, eco-anthropic variables related to beach equipment, vegetation and geomorphological elements were identified and digitalised to analyse spatiotemporal relationships, topographical changes and geomorphological resilience in the study area (Fig. 2). 


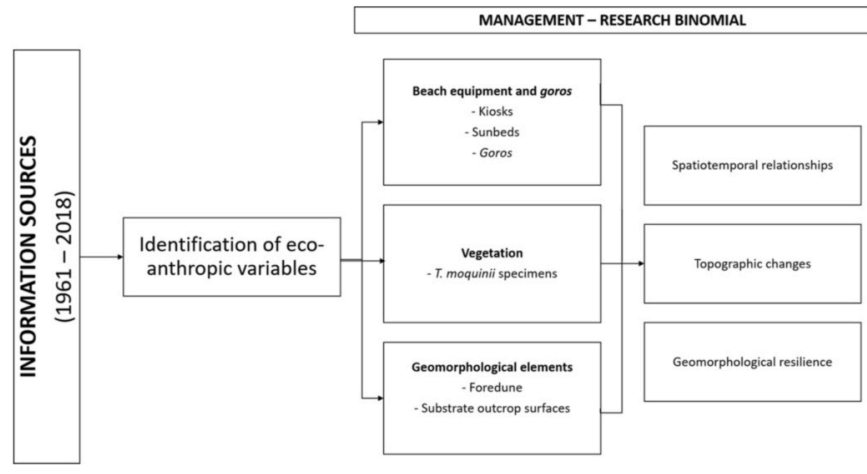

Fig. 2. Flowchart of the methodology carried out in this research.

\subsection{Identification of eco-anthropic variables}

\subsubsection{Beach equipment and goros}

The kiosks and groups of sunbeds were digitalised in polygon-type vectors to obtain the number, surface area and distance between them for each studied year. The goros were also digitalised in point-type vectors to count their number and determine the distance between them.

\subsubsection{Vegetation}

The only plant species that grows in the study area is the nanophanerophyte Traganum moquinii (Hernández-Cordero et al., 2012, 2015). The presence of individual T. moquinii specimens was digitalised creating a point-type vector shapefile in the centroid of the each specimen. The following procedure was undertaken to know the spatiotemporal evolution of the T. moquinii specimens: i) detection of the disappearance of individual specimens between 1961 and 2018, and ii) calculation of the Euclidean distance using specific GIS tools. The distance to the coastline and to the equipment situated on the beach was determined from the eastern boundary of the study area (Fig. 1) towards the interior of the system. Similarly, the northern boundary was used to determine the existence or otherwise of a relationship with the main entrance to the beach-dune system, situated in the Anexo II commercial centre of Playa del Inglés (Fig. 1).

\subsubsection{Geomorphological elements}

3.1.3.1. Foredune. The foredune extends from the first T. moquinii specimens and their sedimentary accumulations (nebkhas, shadow dunes and tongue dunes; Hernández-Cordero et al., 2012; Viera-Pérez, 2015 ) in the first line of the backshore to the last examples of this species which are situated towards the interior of the system, following the prevailing direction of the aeolian sedimentary dynamics (NE-SW). The foredune was digitalised through a polygon-type GIS vector layer.

3.1.3.2. Substrate outcrop surfaces. These erosive depressions of aeolian origin are identified as outcrops of the underlying substrate (wet sand, alluvial deposit and palaeo-reefs, among others) wetted by capillary action. Depending on their origin, they can be interdunal depressions or deflation surfaces.

Interdunal depressions are outcrops of the underlying substrate situated between free dunes (barchan dunes or barchanoid ridges) and associated to displacement of the dunes themselves (natural origin). They are located in mobile dunes found behind the foredune, more than $300 \mathrm{~m}$ inland and at some distance from the structures that alter the

A
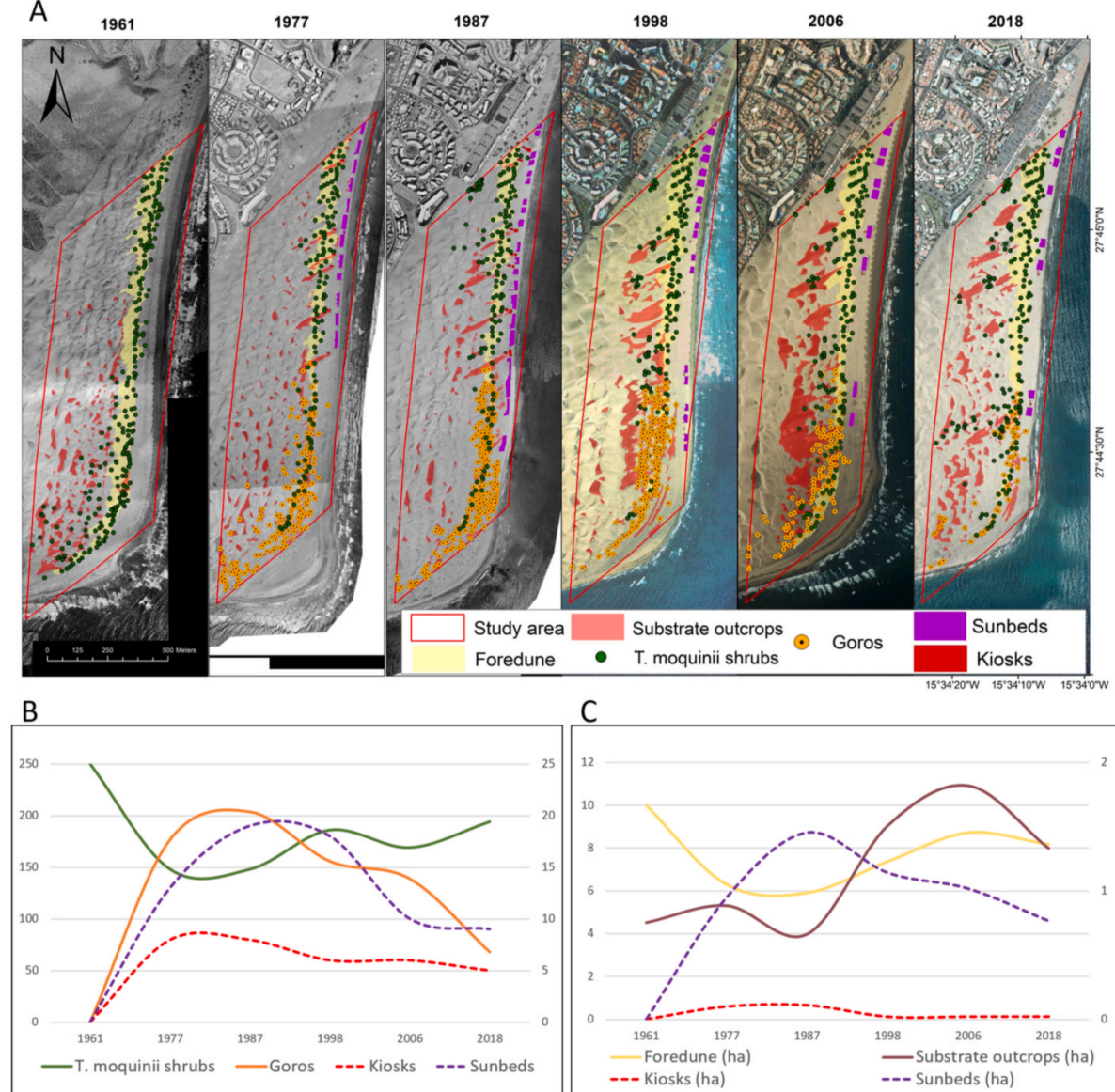

C
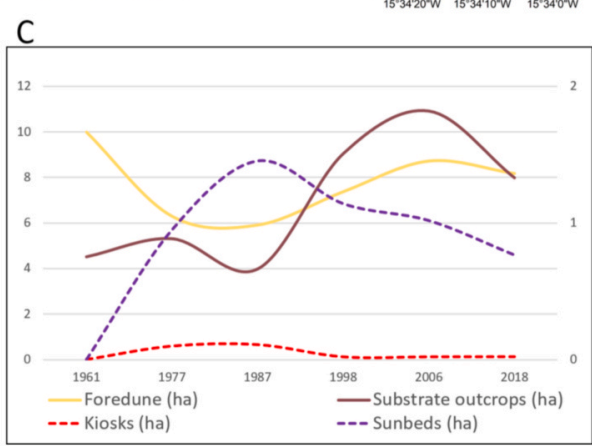

Fig. 3. A. Cartography of the variables. B. Evolution (no.) of variables. C. Evolution (ha) of the variables. Dotted lines are read along the secondary y-axis. 
aeolian sedimentary dynamics ( $>100 \mathrm{~m}$ ). They are oriented parallel to the coast $\left(130^{\circ}-180^{\circ}\right)$. They were digitalised using a polygon-type GIS vector layer. The information about these landforms was unified and is shown together with the deflation surfaces as a single category (substrate outcrops) in Fig. 3. This information was not used for the spatial analyses.

The deflation surfaces are substrate outcrops situated on the backshore and associated to interferences in the aeolian sedimentary dynamics (anthropic origin). They appear near to the foredune $(<300 \mathrm{~m})$ and the artificial structures of kiosks, sunbeds and goros $(<100 \mathrm{~m})$. They are oriented perpendicular to the coast $\left(100^{\circ}-130^{\circ}\right)$ and have a larger surface area than the interdunal spaces. They were mapped using a polygon-type GIS vector layer. Due to their anthropic origin, the information about these erosive landforms (Figs. 5 and 6) was used for the analysis of spatiotemporal relationships with the rest of the variables.

\subsection{Analysis of spatiotemporal relationships}

\subsubsection{Relationships between foredune, beach equipment and deflation surfaces}

A bivariate correlation analysis (Pearson correlation coefficient of 0.95) was undertaken of the spatiotemporal evolution between beach equipment and biogeomorphological elements of the dune system. For this purpose, three N-S profiles were drawn, coinciding with the beach, foredune and back foredune/deflation, separated by a distance of $85 \mathrm{~m}$ (Fig. 1, orange, green and black lines). The following were registered each $2 \mathrm{~m}$ in the direction of the sedimentary dynamics (NE-SW): i) the presence or absence of kiosks or groups of sunbeds in the first profile (beach equipment profile); ii) the presence or absence of foredune in the second profile (foredune profile); and iii) the presence or absence of deflation surfaces in the third profile (back foredune/deflation profile).

\subsubsection{Topographic changes and their correlation with beach equipment}

The topographic profiles were obtained using digital elevation models (DEMs) for 2006 and 2018. The 2011 profile was added to allow better observation of the trends and to reduce the temporal scale. The profiles are located between the back beach and the foredune front (Fig. 1, blue line, elevation profile). The mean density of the original LiDAR data was 1.20 points $/ \mathrm{m}^{2}$, with mean planimetric and altimetric precision ranging around 0.60 and $0.2 \mathrm{~m}$, respectively. The profiles were taken with an elevation datum each $2 \mathrm{~m}$. On this basis, the topographic variations (accumulation and erosion) were detected for this 12-year period.

\subsection{Analysis of geomorphological resilience}

To facilitate the analysis of the capacity of the dune system to preserve its functionality and to support the external agents to which it was exposed over the course of the study period (geomorphological resilience), four plots were established along Playa del Inglés. The plots were situated in areas that were representative of the different spatial combinations of parameters of height, vegetation cover, coastal dune surface area, exposure to wave action, aeolian incidence and anthropic pressure (area occupied by kiosks, sunbeds and parasols). A bivariate analysis was undertaken of pairs of variables between the six selected dates using GIS-based spatial measures on the orthophotos. The calculation of resilience was performed using a set of indicators and following the concepts and metrics set out in Peña-Alonso et al. (2018), which are based on the evaluation of the geomorphological vulnerability of coastal dunes of arid regions. The variables considered and the measurement criteria are represented in Table 2.

After the results of the variables for each year and plot had been obtained, the Geomorphological Resilience (GR; Eq. (1)) value was calculated as the ratio between the sum of the values assigned to each variable (Vi) and the sum of the maximum possible values of geomorphological resilience (Vp max.), following Peña-Alonso et al. (2018):
Table 2

Variables used to calculate geomorphological resilience.

\begin{tabular}{|c|c|c|c|c|c|c|}
\hline \multirow{2}{*}{$\begin{array}{l}\text { GEOMORPHOLOGICAL } \\
\text { RESILIENCE (GR) }\end{array}$} & \multirow[b]{2}{*}{0} & \multirow[b]{2}{*}{1} & \multirow{2}{*}{$\overline{2}$} & \multirow[b]{2}{*}{3} & \multirow{2}{*}{4} & \multirow[b]{2}{*}{ Reference } \\
\hline & & & & & & \\
\hline $\begin{array}{l}\text { 1. Foredune zone surface } \\
\text { variation }(\%)\end{array}$ & $<-30$ & $\begin{array}{l}-11 / \\
-30\end{array}$ & - & $\begin{array}{l}0 /- \\
10\end{array}$ & $>0$ & $\begin{array}{l}\text { Peña-Alonso } \\
\text { (2015) }\end{array}$ \\
\hline $\begin{array}{l}\text { 2. Dry beach surface } \\
\text { variation }(\%)\end{array}$ & $<-100$ & $\begin{array}{l}-16 / \\
-100\end{array}$ & - & $\begin{array}{l}0 /- \\
15\end{array}$ & $>0$ & $\begin{array}{l}\text { Abuodha \& } \\
\text { Woodroffe } \\
\text { (2010) }\end{array}$ \\
\hline 3. Shoreline variation (m) & $<-100$ & $\begin{array}{l}-26 / \\
-100\end{array}$ & - & $\begin{array}{l}0 /- \\
25\end{array}$ & $>0$ & $\begin{array}{l}\text { Gornitz et al. } \\
\text { (1994) }\end{array}$ \\
\hline $\begin{array}{l}\text { 4. Variation in the } \\
\text { continuity of the first } \\
\text { line of nebkhas }(\%)\end{array}$ & $<-30$ & $\begin{array}{l}-11 / \\
-30\end{array}$ & - & $\begin{array}{l}0 /- \\
10\end{array}$ & $>0$ & $\begin{array}{l}\text { Bodere } \\
(1991)\end{array}$ \\
\hline $\begin{array}{l}\text { 5. Variation of maximum } \\
\text { distance between } \\
\text { individual plant } \\
\text { specimens in the first } \\
\text { line of nebkhas (\%) }\end{array}$ & $>30$ & $21-30$ & - & $0-20$ & $<0$ & $\begin{array}{l}\text { Peña-Alonso } \\
\text { (2015) }\end{array}$ \\
\hline $\begin{array}{l}\text { 6. Vegetation cover } \\
\text { variation in the } \\
\text { foredune zone }(\%)\end{array}$ & $<-50$ & $\begin{array}{l}-26 /- \\
50\end{array}$ & - & $\begin{array}{l}<0 /- \\
25\end{array}$ & $>0$ & $\begin{array}{l}\text { Bodere } \\
(1991)\end{array}$ \\
\hline
\end{tabular}

$G R=V_{i} / V_{p \max }$

\section{Results and discussion}

\subsection{Spatiotemporal evolution of the geomorphological and anthropic elements}

Between 1961 and 2018 several variations were detected in the different eco-anthropic variables studied in the dunefield. These variations are principally related to the role played by beach equipment and user activities, as well as measures taken by the competent authorities. These management actions have, in turn, been based on advances in scientific knowledge acquired in recent decade, especially in reference to how the aeolian sedimentary systems of the Canary Islands function and the impacts generated by human activities. Knowing the evolution over time of the management of this protected nature area is key to understanding the environmental changes that have been detected.

Initiatives began in the 1970s to protect the dunefield, but it was not until the 1980s that measures were enacted in law to protect and preserve the system. Such measures included municipal subsidiary regulations (1986) on land use, the first law that established Nature Areas in the Canary Islands (1987), which included Maspalomas as a protected area, and the Coastal Act of 1988 which placed restrictions on the use of beaches and sandy areas. The 12/1987 law on Nature Areas was replaced by a law $(12 / 1994)$ which declared the dune system and its immediate surroundings to be a Special Nature Reserve and an Area of Ecological Sensitivity. As a result of this law, a Nature Reserve Master Plan was drawn up in 1999, which oblige to the declaration of ecological impact of any management activity on its beaches, as well as the taking of measures that affect the back beach and the foredune, such as the goros removal. In the early 2000s, the approval of new land-use planning laws leaves beach management out of the ecological impact statement. In 2004, a new Master Plan was approved promoting the planting of specimens of T. moquinii where they had disappeared, and management of the beach became the responsibility of the Coastal Authority and the Local Council of San Bartolomé de Tirajana who intensified management actions concentrating on using heavy machinery to correct the alterations that had been detected as the result of the impact of beach equipment. A new project, established by the Ministerio de Medio Ambiente (2007) integrated all the knowledge that had been acquired on the Maspalomas dune system, establishing a new scenario based on the need for a more environment-centred focus and management strategy. Some of the proposed management measures are presently being put into action through the Masdunas + programme (2018) established 
by the Cabildo Insular de Gran Canaria.

\subsubsection{Beach equipment}

As tourism began to develop in Playa del Inglés in the 1960s, so too did the installation of beach equipment on the backshore. The number of groups of sunbeds and, consequently, the surface area occupied by them grew constantly up to 1987, initially in the northern and central area of the beach and then extending southwards during the 1980s (Fig. 3). A redistribution of the groups of sunbeds took place between 1987 and 1988 , with a subsequent reduction in the area occupied by them through the disappearance one of the groups of sunbeds. A further reduction in these groups of sunbeds took place in the following years, with the most important of the measures that were taken in this respect being the obligation that was established in 2007 to stack the sunbeds when not in use. As a result, in 2018 a total of 9 groups of sunbeds occupied a surface area of 0.75 ha.

Analogously, the presence of kiosks increased in the 1970s, reaching their maximum number and maximum occupied surface area in 1977 (Fig. 3). These values remained virtually constant up to 1987. The kiosks in this first period ranged in size between $105 \mathrm{~m}^{2}$ and $120 \mathrm{~m}^{2}$. Between 1987 and 1998 the number of and surface area occupied by the kiosks fell. The designation of Playa del Inglés as an Area of Ecological Sensitivity (1994) resulted in new measures being taken with respect to the kiosks in the first decade of this century. The position of a total of 6 modular and detachable kiosks (smaller than $20 \mathrm{~m}^{2}$ ) had to be changed on a regular basis. A study conducted by the Ministerio de Medio Ambiente (2007) recommended a redesign of the kiosks, using a more aerodynamic form. Despite this, in 2018, 5 rectangular-shaped kiosks occupying a surface area of 0.02 ha were detected in the present study.

\subsubsection{Goros}

Between 1961 and 1977 there began to appear in the central and southern areas of the beach windbreak structures known locally as goros. The highest number of these structures (over 200) was detected for 1987, after which they gradually decreased in number until 1999 when the Nature Reserve Master Plan expressly prohibited their construction and existing structures began to be removed. The 2004 Nature Reserve Master Plan focussed again on the need to eliminate these structures, although only those which were not associated to specimens of T. moquinii were removed.

\subsubsection{Traganum moquinii}

As reported in previous studies, an overall reduction in the number of specimens of T. moquinii in the Maspalomas dunefield has taken place since 1961 (\Hernández-Cordero et al., 2012, 2017). This evolutionary dynamic is observed even if only the area included in the present study is considered (Fig. 3A). The highest decrease of $40.8 \%$ took place between 1961 (before the development of tourism) and 1977. Since then, there has been a series of rises and dips in the numbers of specimens: an increase between 1987 and 1998 of $25.7 \%$, a decrease of $9.1 \%$ between 1998 and 2006, and an increase of 14.8\% between 2006 and 2018.

Two spatial patterns can be observed in the evolution of the populations of T. moquinii (Fig. 4). Firstly, most of the losses take place in the first $200 \mathrm{~m}$ from the coast. Most beach users are concentrated in this strip, either on or close to the beach, sunbeds and kiosks. In this respect, the grouping together of beach equipment in certain areas of the beach (generally the kiosks are situated between groups of sunbeds) generates user focal points of concentration. Beach user access to areas where beach equipment is concentrated is liable to generate other impacts on biogeomorphological elements of the systems, caused by stepping or trampling on the vegetation making the growth of new specimens and the formation of embryonic dunes more difficult (Hernández-Cordero et al., 2017). Secondly, the reduction is greater in the northern and southern sections of the study area compared to the central section. Previous studies have reported that these higher reductions in the northern and southern sections may be related to the degree of tourist

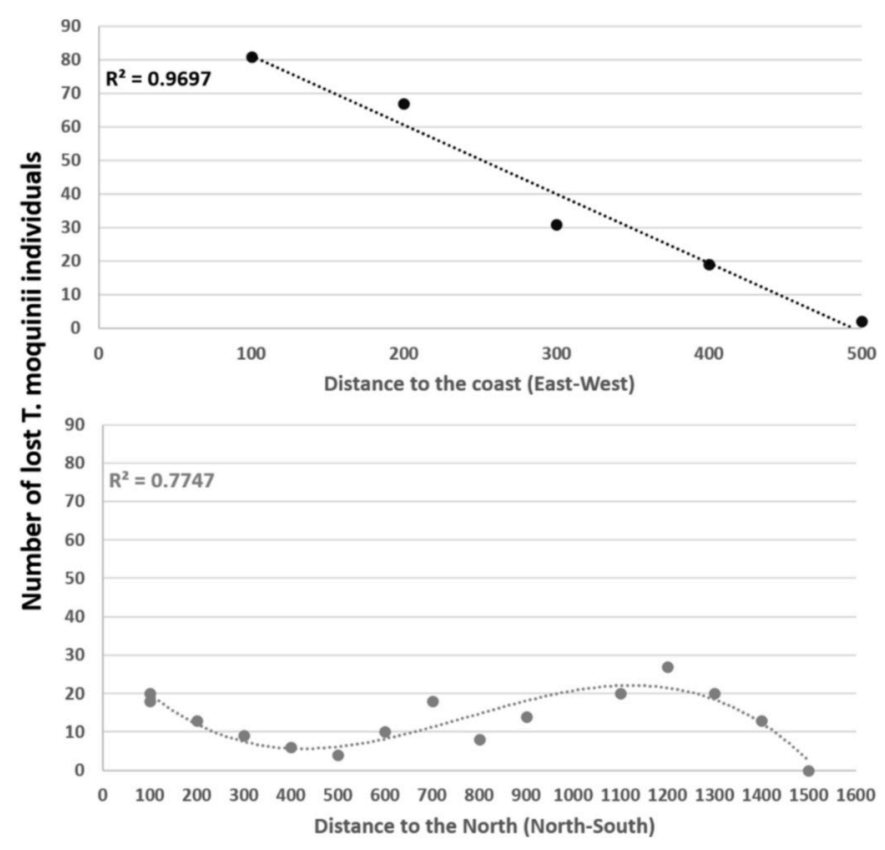

Fig. 4. Spatial analysis of T. moquinii individuals lost between 1961 and 2018.

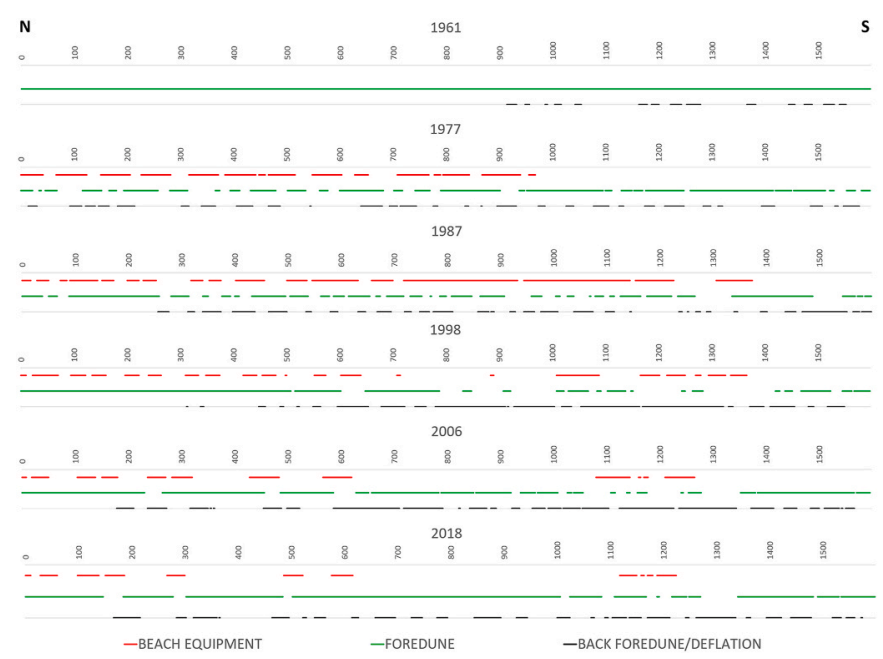

Fig. 5. Spatiotemporal analysis of the presence of beach equipment (red, in the beach equipment profile), foredune (green, in the foredune profile) and deflation surfaces (black, in the back foredune/deflation profile). (For interpretation of the references to colour in this figure legend, the reader is referred to the Web version of this article.)

activity (Hernández-Cordero et al., 2017). That is, the reduction in the northern area may be associated to its closeness to the urbanised area of the resort and therefore to a greater number of beach users affecting individual specimens of T. moquinii. The reduction in the southern section may be related to the alteration of aeolian dynamics as a consequence of the development of the touristic resort on the Playa del Inglés terrace. It is also possible that the plants were directly destroyed at some point to expand the beach area available for tourists.

\subsubsection{Substrate outcrops}

Outcrop areas of the underlying substrate in 1961 were detected principally in the southern section of Playa del Inglés. These areas were small and produced no fragmentation of the foredune. Between 1977 and 1987 an increase was observed in the number of deflation surfaces, although the area they occupied decreased. In this period, however, 

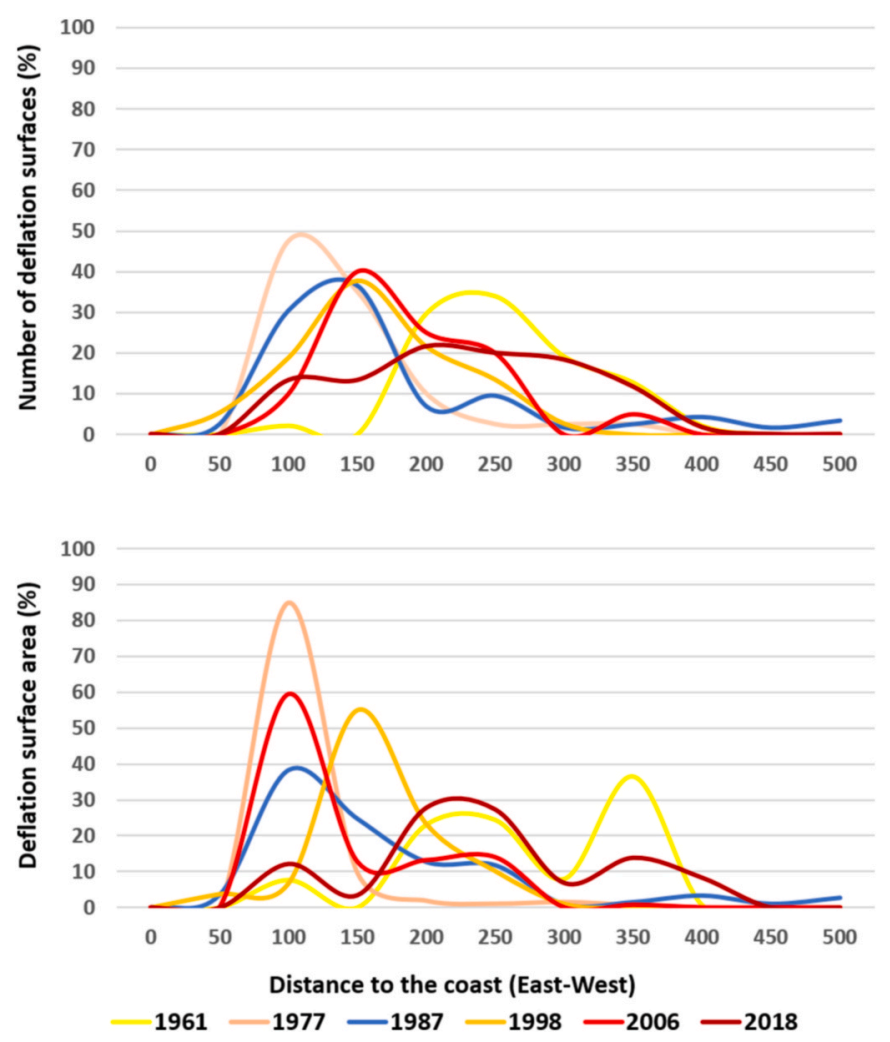

Fig. 6. Location and displacement of deflation surfaces and occupied area.

these deflation surfaces began to fragment the foredune in the northern and central sections. A decrease in the surface area occupied by these outcrops was detected for 1987. Between 1987 and 2006 the number of deflation surfaces decreased but increased in size. Their displacement towards the interior of the system was also observed, with large deflection surfaces detected behind the foredune. The area occupied by substrate outcrops recovered slightly between 2006 and 2018, amounting to almost 8 ha in the latter of the two years (Fig. 3).

The formation of these substrate outcrops, perpendicular to the coast and located on the beach, on the foredune and in the back foredune (Fig. 3) indicates an erosional process (Díaz Guelmes and Hernández-Calvento, 2004; Hernández-Calvento et al., 2014). This occurrence is comparable to the formation of blowouts that occurs commonly in temperate regions (Leatherman, 1976; Saunders and Davidson-Arnott, 1990; Mir-Gual et al., 2013). The fact that blowouts have not been observed around, or on the foredune of this environment is related to the differences between arid and temperate foredunes, as the vegetation cover is lowest in the arid systems and bushes predominate (Garcia-Romero et al., 2021).

\subsubsection{Foredune}

In 1961, the foredune of Playa del Inglés situated in the study area occupied a continuous extension of 10 ha. A continuous north-to-south foredune was observed with no fragmentations, although some 14 smallsized deflation surfaces appeared in the south. Progressive fragmentation of the foredune took place in the following years at the same time as the number of individual T. moquinii specimens decreased, as determined in previous studies (Hernández-Cordero et al., 2012). The management measures that were taken during the study period were at least partly responsible for the changes detected (Fig. 3). The reduction in the area occupied by the foredune that took place between 1977 and 1987 was greater than between 1961 and 1977. This higher foredune loss coincides with the period of the highest loss of $T$. moquinii specimens in the study area. In 1977 the first discontinuities appear in the foredune, concentrated in the northern and central section of the beach. In 1987, the area occupied by the foredune is the lowest in the whole study period. There are clear discontinuities along the beach which resulted in a foredune surface area of less than 6 ha. The management measures adopted in the 1990s appear to have favoured a gradual recovery of the area occupied by the foredune up to 2006. Between 2006 and 2018 this trend is reversed, and once again there is a loss of surface area occupied by the foredune (Fig. 3).

Unlike the foredune of temperate regions, where the main indicator of degradation is the presence of blowouts (Hesp, 2002), these results show that the effect of degradation of an arid foredune is the reduction of T. moquinii specimens and nebkhas, as well as the formation of deflation surfaces and free mobile landforms (small barchan dunes with less than $1 \mathrm{~m}$ high and sand sheets) (Hernández-Cordero et al., 2012, 2018; Hernández-Calvento et al., 2014).

\subsection{Spatiotemporal relationships between biogeomorphological and anthropic elements}

Analysing the joint spatiotemporal distribution of beach equipment and biogeomorphological variables of the dunefield between 1961 and 2018 enables determination of cause-effect relationships in the historical transformations observed in Playa del Inglés (Figs. 5 and 7).

As this is a transgressive dune system, where sedimentary transport is initiated on the beach, the characteristic natural processes that take place in beach-dune, foredune and interior area subsystems are connected, with any interference that is produced in the beach having possible repercussions throughout the system.

The maximum joint presence of $T$. moquinii and foredune over the course of the study period was in 1961 (Fig. 3), and the minimum 16 years later in 1977, with this period coinciding with the expansion of tourism and the maximum number of kiosks (1977) and goros (1977-1987) on the beach (Figs. 3 and 5). The pattern described by this joint presence coincides with the appearance and increase between the 1960 s and 1987 of the number of goros, kiosks and sunbeds and in the amount of surface area occupied by kiosk and sunbeds (Fig. 3B and C). From 1987 to 2018, the T. moquinii shrubs and the foredune tended to progressively recover at the same time as the presence of beach equipment (sunbeds and kiosks) and goros tended to decrease (Fig. 3B and C), which coincides with the declaration in 1987 of the Maspalomas dunefield as a protected natural area. These beach structures decreased
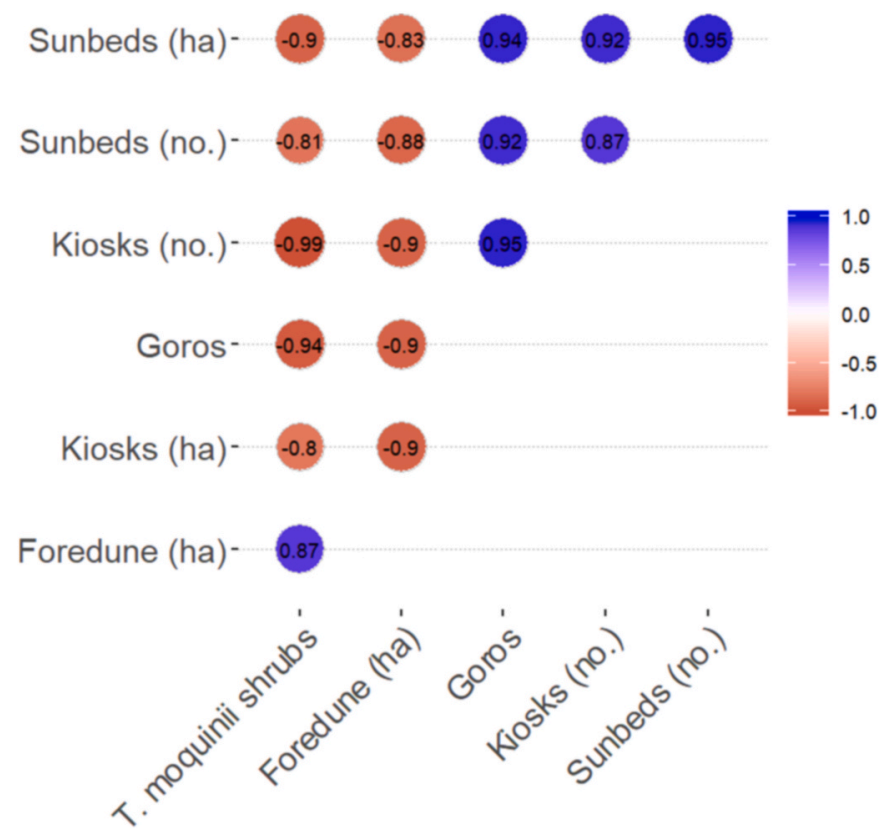

Fig. 7. Pearson correlations between the studied variables (p-value $<0.05$ ). 
from 1987 onwards, which is when an incremental trend in the number of $T$. moquinii specimens is also detected. The inverted correlation between vegetation cover/foredune size and the presence of goros is especially notable in the southern section of the beach (Figs. 3 and 5), where it is also possible that the decrease in T. moquinii is related to alteration of the aeolian sedimentary dynamics of the urbanisation of the Playa del Inglés terrace, and/or their direct removal to expand the beach area available for tourists (Hernández-Cordero et al., 2017).

The deflation surfaces followed a trend of progressive expansion from 1961 to at least 2006, despite the progressive decrease from 1987 onwards of beach equipment (kiosks and sunbeds) and goros and the progressive recovery of the foredune and T. moquinii specimens (Fig. 3B and $\mathrm{C}$ ). The coastal sections most affected by the deflation processes over time strongly coincide with the location of the main beach structures (kiosks, groups of sunbeds and goros) and with the sections where there was a greater decrease in surface area occupied by the foredune and in the number of individual T. moquinii specimens (Fig. 4). In the case of Playa del Inglés, plastic netting was on occasions positioned around the sunbed sectors to protect users from the wind. This netting would have constituted an added obstacle to aeolian sedimentary transport and contributed to the development and permanence of deflation surfaces. Their persistence may be due to the strong inertia of this type of erosive landform, which once the process for their development has been triggered tends to be difficult to invert. These deflation surfaces may well be inherited effects from the 1970s and 1980s of the first kiosks and groups of sunbeds (Suárez Rodríguez and Hernández-Calvento, 1998).

The origin of the deflation surfaces is nevertheless difficult to precisely determine given that, as previously indicated, they are erosive aeolian landforms which are not easily reversible. Henández-Calvento (2006) suggests that beach equipment, comprised mainly of kiosks, sunbeds and parasols, and windbreaks constructed by beach users, would have altered over the years the aeolian sedimentary dynamics, impeding sedimentary transport, causing deterioration to the foredune, and generating deflation surfaces. Although the deflation surfaces may decrease in number, generally they tend to increase in size over time (Fig. 3C). It can be seen in Fig. 6 that in 1961 (yellow), these deflation surfaces (frequency and area percentages) were principally situated 200 $\mathrm{m}$ or more from the coastline. However, between 1977 and 1998 (pink, blue and orange), the areas occupied are displaced towards the first $100-150 \mathrm{~m}$ from the coastline, and in 1987 and 1998 deflation surfaces are even found in the first $50 \mathrm{~m}$. These years coincide with an important increase in the services offered to beach users in Playa del Inglés. With respect to this coastal strip, there is also a correlation with the areas where the main beach equipment (kiosks, groups of sunbeds) and goros are situated and where the highest loss of T. moquinii specimens was detected, as explained previously (Fig. 4). In this respect, in combination with the results shown in Fig. 5, there are clear signs that these environmental changes are related to beach equipment and man-made windbreaks, with a cause-effect process altering biogeomorphological processes in the Maspalomas beach-dune system. The impact of beach equipment is similar to that of rigid structures like buildings (the effect of which has been studied in greater detail), altering the incidence of the wind and thereby affecting aeolian sedimentary dynamics and transport in the areas that surround them (Smith et al., 2017). At the same time, complex airflow patterns are generated, causing sediment to diverge around and above the structure and creating turbulence, particularly behind it (Fackrell, 1984; Hunt, 1971; Peterka et al., 1985). These latter processes can also alter biogeomorphological elements, generating deflation surfaces downwind of the structure (García-Romero et al., 2019b). In 2006 (light red) and 2018 (dark red), a slight inland displacement is again seen of the deflation surfaces $(200 \mathrm{~m}+$ from the coast). This displacement, especially in terms of area percentage, coincides with the foredune recovery that can observed in Fig. 5. However, the recovery process tends to be slow and at the present time this coastal strip ( $200 \mathrm{~m}+$ from the coast) is more affected than in 1961 with a higher number of eroded surfaces. This deterioration could be the result of effects inherited from the installation of kiosks and sunbeds in the 1970 s and 1980s, with the impact of these structures continuing over time despite the reduction in the surface area they occupy and their relocation on the beach (Suárez Rodríguez and Hernández-Calvento, 1998).

All the above reinforces the idea of the relationship between these artificial beach structures and their impact not only in the distribution and presence of $T$. moquinii specimens, but also in the size and morphology of the foredune. This relationship was hypothesised in previous studies (Hernández-Calvento, 2006; Hernández-Cordero et al., 2012; Garcia-Romero et al., 2021), but not directly analysed. In general, it can be seen that the fragmentation of the foredune and the reduction in the number of $T$. moquinii specimens is related to the greater presence and abundance of beach equipment. The same behaviour is observed with the growth in the number and size of deflation surfaces. In addition, in the case of the southern section of the beach the correlation is increased due to the presence of goros.

The Pearson coefficients (Fig. 7) provide further evidence of the relationships observed between biogeomorphological transformations of the dune systems and the variables associated to human activity on the beach. The backshore presence of structures, in the form of kiosks, groups of sunbeds and goros, is inversely correlated to the number of T. moquinii specimens and the surface area occupied by the foredune. Particularly notable are the correlations between the numbers of kiosks $\left(\mathrm{R}^{2}=-0.99\right)$ and goros $\left(\mathrm{R}^{2}=-0.94\right)$ and the abundance of $T$. moquinii specimens.

\subsection{Recent topographical evolution of beach and foredune}

Fig. 8 shows the topographic variations (Fig. 1, elevation profile) (accretion and erosion) and their correlation with the presence or absence of beach equipment along the beach (Fig. 1, beach services profile) between 2006 and 2018. In this period, $27.75 \%$ of the profile shows accretion and $72.25 \%$ erosion, and it was also observed that the losses mainly coincide with areas permanently occupied by beach equipment. However, where no such equipment was detected the topographic profile remains stable or even shows accumulation (especially in the central sector). In the southern tip, an irregular profile is observed with zones of accretion and accumulation. Like buildings, beach equipment are obstacles that can spatially divide beach and dune and, consequently, reduce the area where aeolian sedimentary transport takes place (García-Romero et al., 2016; Morton et al., 1994). That is, a barrier is formed that separates the dunes and foredune from its sediment sources (Jackson and Nordstrom, 2011).

\subsection{Geomorphological resilience}

The results of the analysis by plots show a very low degree of beachdune resilience according to the variations in foredune surface area, continuity in the first line of nebkhas and foredune vegetation cover (Table 3). These three variables are related to the functional structure of the coastal dune, indicating that its capacity to support the natural and anthropic impacts that might affect it is being weakened. This loss of capacity is particularly notable in the southernmost plot of the study area (Plot 4), where there was a $43.34 \%$ loss in surface area, a $25.38 \%$ loss in the continuity of the foredune front, and a $27.66 \%$ loss in

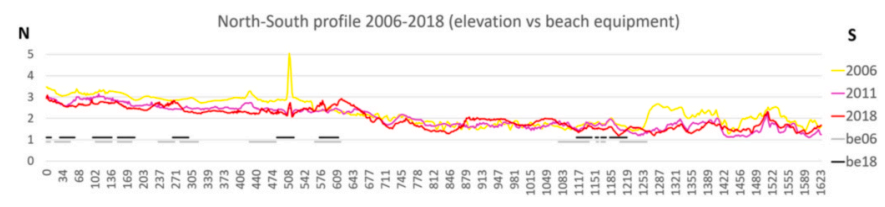

Fig. 8. Elevation profiles (m) (N-S) from 2006 to 2018 and the presence of beach equipment in the study area. Key: be-beach equipment. 
Table 3

Main results in geomorphological resilience variables (degrees of freedom $=4$ ).

\begin{tabular}{lll}
\hline Geomorphological resilience variables & Mean & $\begin{array}{l}\text { Standard } \\
\text { deviation }\end{array}$ \\
\hline 1. Foredune zone surface variation (\%) & 2.56 & 1.46 \\
2. Dry beach surface variation (\%) & 3.00 & 0.89 \\
3. Shoreline variation (m) & 3.25 & 0.77 \\
4. Variation in the continuity of the first line of nebkhas & 2.63 & 1.50 \\
(\%) & & \\
5. Variation of maximum distance between plant & 3.00 & 1.41 \\
$\quad$ specimens in the first line of nebkhas (\%) & & \\
6. Vegetation cover variation in the foredune zone (\%) & 2.75 & 1.44 \\
\hline
\end{tabular}

foredune vegetation cover in the final period analysed (2006-2018).

These negative results obtained in the last of the periods analysed are related to the trend observed in all the plots (Fig. 9). While geomorphological resilience may have experienced other dips (as in the period between 1977 and 1987), the last decade analysed shows the worst result. In general, an enduring geomorphological deterioration is observed of beach and backshore at functional level, with detection of foredune fragmentation and the ongoing development of deflation surfaces.

This is additionally verified in the study of topographic profile variations (Fig. 8), foredune fragmentation (Figs. 3 and 5), and the evolution and displacement of deflation surfaces, with the latter analysis also reflecting the difficulty that these landforms have to recover or disappear (Fig. 6). In this respect, future studies should be considered for the construction of indices that integrate both environmental and anthropic variables, as they may provide more critical results closer to the actual reality. Additionally, if the intention is to provide integrated management and at the same time undertake the restoration and/or preservation of a system (in this case the beach-dune system of Maspalomas and particularly the foredune), special attention should be paid to processes that integrate all of its natural and socio-economic elements (Gracia Prieto et al., 2009; Lithgow et al., 2015; Peña-Alonso et al., 2018), as well as consider strategies to the respond to different environmental scenarios, such as sea level rise (Nazarnia et al., 2020).

\section{Conclusions}

This research presents innovative results about the impacts of beach equipment on an arid beach-dune system subjected to an intensive and continuous human pressure. Significant transformations have been found in the morphology and physical structure of the foredune of an arid dunefield, as well as statistically significant spatiotemporal correlations between these biogeomorphological transformations and beach equipment installed in the area. This supports the initial hypothesis of the potential influence of beach management on the transformation of the beach-dune system. Moreover, the biogeomorphological processes have responded to different management measures over the years, and it was found that some of the effect on these processes that had their origin in the 1970s and 1980s (development and increase in tourist activities in Gran Canaria without environmental protection) are not only detectable but have been inherited in the present day. Although that some of the considered variables seem to demonstrate a degree of recovery in the study area when analysed individually, coinciding with some of the improvements that have been made in terms of environmental protection (declaration as protected natural area since 1987) and management measures (since the 1990s), it should be noted that when integrated in an index designed to evaluate geomorphological resilience it was found that the system has been deteriorated and not recovered.

The results obtained in this study are conducive to a reflection on how environmental management measures can have a determining influence on the conservation or degradation of environments and ecosystems and, in particular, of arid beach-dune systems. It is important to underline the close collaboration that must exist between management

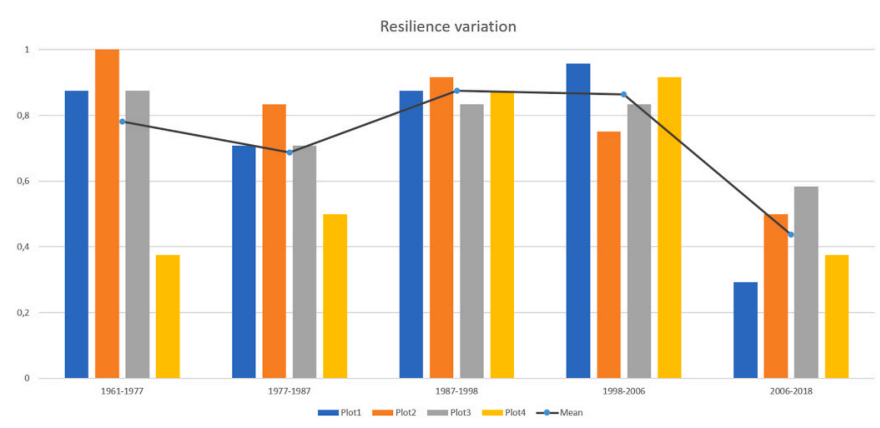

Fig. 9. Geomorphological resilience variation of representative plots along Playa del Inglés.

and research organisations to ensure the effective management of these spaces (management-research binomial). This ensures the application of management strategies based on scientific knowledge and know-how, as well as the undertaking of further research studies aimed at continuously and efficiently improving the management of such areas.

\section{Author statement}

Abel Sanromualdo-Collado, Data curation, Formal analysis, Investigation, Methodology, Writing - original draft, Writing - review \& editing. Leví García-Romero, Data curation, Formal analysis, Writing original draft, Writing - review \& editing. Carolina Peña-Alonso, Data curation, Formal analysis. Antonio I. Hernández-Cordero, Data curation, Supervision, Validation, Writing - review \& editing. Nicolás FerrerValero, Data curation, Formal analysis. Luis Hernández-Calvento, Supervision, Writing - review \& editing, Funding acquisition.

\section{Declaration of competing interest}

The authors declare that they have no known competing financial interests or personal relationships that could have appeared to influence the work reported in this paper.

\section{Acknowledgements}

This work is a contribution of project CSO2016-79673-R (National R\&D\&i Plan, Spain) co-financed with ERDF funds and of the cooperation program INTERREG-MAC 2014-2020, project PLANCLIMAC (MAC/ $3.5 \mathrm{~b} / 244)$. First author is beneficiary of a PhD contract of the Spanish Ministry of Economy, Industry and Competitiveness, supported by the European Social Fund (ESF). Dr. Leví This article is a publication of the Unidad Océano y Clima of the Universidad de Las Palmas de Gran Canaria, an R\&D\&i CSIC-associate unit. The second author is supported by a research contract of the Agency of Research, Innovation and Information Society of the Canary Island Government, co-financed with ERDF funds.

\section{References}

Abuodha, P.A.O., Woodroffe, C.D., 2010. Assessing vulnerability to sea-level rise using a coastal sensitivity index: a case study from southeast Australia. J. Coast Conserv. 14, 189-205. https://doi.org/10.1007/s11852-010-0097-0.

Amini, A., Moussavi-Harami, R., Lahijani, H., Mahboubi, A., 2012. Sedimentological, geochemical and geomorphological factors in formation of coastal dunes and nebkha fields in Miankaleh coastal barrier system (Southeast of Caspian Sea, North Iran). Geoscience Journal 16(2), 139-152. DOI: 10.1007/s12303-012-0014-7.

Barbier, E.B., Hacker, S.D., Kennedy, C., Koch, E.W., Stier, A.C., Silliman, B.R., 2011. The value of estuarine and coastal ecosystem services. Ecol. Monograph 81, 169-193. https://doi.org/10.1890/10-1510.1.

Bauer, B.O., Sherman, D.J., 1999. Coastal dune dynamics: problems and prospects. In: Goudie, A.S., Livingston, I., Stokes, S. (Eds.), Aeolian Environments, Sediments and Landforms. John Wiley \& Sons, Ltd, London, pp. 71-104.

Bodere, J.C., 1991. La gestion des milieux dunaires littoraux. Evaluation de leur vulnerabilite a partir d'une liste de controle. Etude de cas dans le sud du Pays de 
Galles et en Bretagne occidentale. Norois 151, 279-298. https://doi.org/10.3406/ noroi.1991.6371.

Burton, R., 1991. Travel Geography. Pitman Publishing, London.

Cabrera-Vega, L.L., Cruz-Avero, N., Hernández-Calvento, L., Hernández-Cordero, A.I., Fernández-Cabrera, E., 2013a. Morphological changes in dunes as an indicator of anthropogenic interferences in arid dune fields. J. Coast Res. 165, 1271-1276. https://doi.org/10.2112/SI65-215.1.

Cabrera-Vega, L.L., Hernández-Cordero, A.I., Viera-Pérez, M., Cruz-Avero, N., Hernández-Calvento, L., 2013b. Caracterización de una duna costera de zona árida: Maspalomas (Gran Canaria). Geotemas 14, 107-110.

Cham, D.D., Son, N.T., Minh, N.Q., Thanh, N.T., Dung, T.T., 2020. An analysis of shoreline changes using combined multitemporal remote sensing and digital evaluation model. Civ. Eng. J. 6, 1-10. https://doi.org/10.28991/cej-202003091448 .

Corbau, C., Simeoni, U., Melchiorre, M., Rodella, I., Utizi, K., 2015. Regional variability of coastal dunes observed along the Emilia-Romagna littoral. Italy. Aeolian Research 18 169-183. https://doi.org/10.1016/j.aeolia.2015.07.001.

de Andrés Díaz, J.R., Gracia Prieto, F.J., 2002. La franja litoral: riesgos y protección. In: Ayala Carcedo, F.J., Olcina Cantos, J. (Eds.), Riesgos Naturales. Ariel, Madrid, pp. 1023-1058.

Del Río, J., Malvárez, G., 2017. Erosión costera y acumulación de sedimentos en los embalses: el caso de La Concepción en la Ensenada de Marbella. Geotemas 17, 251-254.

Díaz Guelmes, G., Hernández-Calvento, L., 2004. Análisis de la evolución de las superficies de deflación eólica en la Playa de El Inglés (Gran Canaria, islas Canarias) mediante técnicas de fotointerpretación y teledetección. In: Conesa García, C. Álvarez Rogel, Y., Mártinez Guevara, J.B. (Eds.), Medio Ambiente, Recursos y Riesgos Naturales: Análisis Mediante Tecnología SIG y Teledetección. Asociación de Geógrafos Españoles, Murcia, pp. 177-187.

Domínguez-Brito, A.C., Cabrera-Gámez, J., Viera-Pérez, M., Rodríguez-Barrera, E. Hernández-Calvento, L., 2020. A DIY low-cost wireless wind data acquisition system used to study an arid coastal foredune. Sensors 20 (1064). https://doi.org/10.3390/ s20041064.

European Environment Agency, 2006. The changing faces of Europe's coastal areas. Publ. Eur. Communities.

Everard, M., Jones, L., Watts, B., 2010. Have we neglected the societal importance of sand dunes? An ecosystem services perspective. Aquat. Conserv. Mar. Freshw. Ecosyst. 20, 479-487. https://doi.org/10.1002/aqc.1114.

Fackrell, J.E., 1984. Parameters characterising dispersion in the near wake of buildings. J. Wind Eng. Ind. Aerod. 16, 97-118. https://doi.org/10.1016/0167-6105(84) 90051-5.

Ferrer-Valero, N., Hernández-Calvento, L., Hernández-Cordero, A.I., 2017. Human impacts quantification on the coastal landforms of gran Canaria island (canary islands). Geomorphology 286, 58-67. https://doi.org/10.1016/j. geomorph.2017.02.028.

García-Romero, L., Hernández-Cordero, A.I., Fernández-Cabrera, E., Peña-Alonso, C. Hernández-Calvento, L, Pérez-Chacón, E, 2016. Urban-touristic impacts on the aeolian sedimentary systems of the Canary Islands: conflict between development and conservation. Islam Stud. J. 11, 91-112.

García-Romero, L., Delgado-Fernández, I., Hesp, P.A., Hernández-Calvento, L., Hernández-Cordero, A.I., Viera-Pérez, M., 2019a. Biogeomorphological processes in an arid transgressive dunefield as indicators of human impact by urbanization. Sci. Total Environ. 650, 73-86. https://doi.org/10.1016/j.scitotenv.2018.08.429.

García-Romero, L., Delgado-Fernández, I., Hesp, P.A., Hernández-Calvento, L., VieraPérez, M., Hernández-Cordero, A.I., Cabrera-Gámez, J., Domínguez-Brito, A.C., $2019 \mathrm{~b}$. Airflow dynamics, vegetation and aeolian erosive processes in a shadow zone leeward of a resort in an arid transgressive dune system. Aeolian Res. 38, 48-59. https://doi.org/10.1016/j.aeolia.2019.03.006.

Garcia-Romero, L., Hernández-Cordero, A.I., Hesp, P.A., Hernández-Calvento, L., Santana del Pino, A., 2021. Decadal monitoring of Traganum moquinii's role on foredune morphology of an human impacted arid dunefield. Sci. Total Environ. 758, 143802 https://doi.org/10.1016/j.scitotenv.2020.143802.

Gómez Martín, M.B., 2005. Weather, climate and tourism: a geographical perspective. Ann. Tourism Res. 32, 571-591. https://doi.org/10.1016/j.annals.2004.08.004.

Gornitz, V.M., Daniels, R.C., White, T.W., Birdwell, K.R., 1994. The development of a coastal risk assessment database: vulnerability to sea-level rise in the U.S. Southeast. J. Coast. Res. SI12 327-338. https://doi.org/10.2307/25735608.

Gracia Prieto, F.J., Sanjaume, E., Hernández-Calvento, L., Hernández-Cordero, A.I, Flor, G., Gómez-Serrano, M.A., 2009. Dunas marítimas y continentales. In: Bases Ecológicas Preliminares Para La Conservación de Los Tipos de Hábitat de Interés Comunitario En España. Ministerio de Medio Ambiente, y Medio Rural y Marino, Madrid (Spain), p. 106

Hernández-Calvento, L., 2002. Análisis de la evolución del sistema de dunas de Maspalomas. Gran Canaria, Islas Canarias.

Hernández-Calvento, L., 2006. Diagnóstico sobre la evolución del sistema de dunas de Maspalomas. Cabildo Insular de Gran Canaria, Las Palmas de Gran Canaria.

Hernández-Calvento, L., Jackson, D.W.T., Medina, R., Hernández-Cordero, A.I., CruzAvero, N., Requejo, S., 2014. Downwind effects on an arid dunefield from an evolving urbanised area. Aeolian Res. 15, 301-309. https://doi.org/10.1016/j. aeolia.2014.06.007.

Hernández-Cordero, A.I., Pérez-Chacón Espino, E., Hernández-Calvento, L., 2012. La investigación como soporte de la gestión: el ejemplo de la duna costera (foredune) de Maspalomas (Gran Canaria, Islas Canarias). La gestión Integr. Play, y dunas Exp, en Latinoamérica y Eur. Monogr. la Soc.. d'Història Nat. les Balear 19, 289-306.

Hernández-Cordero, A.I., Pérez-Chacón Espino, E., Hernández-Calvento, L., 2015. Vegetation, distance to the coast, and aeolian geomorphic processes and landforms in a transgressive arid coastal dune system. Phys. Geogr. 36, 60-83. https://doi.org/ $10.1080 / 02723646.2014 .979097$.

Hernández-Cordero, A.I., Hernández-Calvento, L., Pérez-Chacón Espino, E., 2017. Vegetation changes as an indicator of impact from tourist development in an arid transgressive coastal dune field. Land Use Pol. 64, 479-491. https://doi.org/ 10.1016/j.landusepol.2017.03.026.

Hernández-Cordero, A.I., Hernández-Calvento, L., Hesp, P.A., Pérez-Chacón, E., 2018. Geomorphological changes in an arid transgressive coastal dune field due to natural processes and human impacts. Earth Surf. Process. Landforms 43, 2167-2180. https://doi.org/10.1002/esp.4382.

Hernández-Cordero, A.I., Peña-Alonso, C., Hernández-Calvento, L., Ferrer-Valero, N., Santana-Cordero, A.M., García-Romero, L., Pérez-Chacón Espino, E., 2019. Aeolian sedimentary systems of the canary islands. In: Morales, J.A. (Ed.), The Spanish Coastal Systems. Springer International Publishing, Cham, pp. 699-725. https://doi. org/10.1007/978-3-319-93169-2_30.

Hesp, P.A., 2002. Foredunes and blowouts: initiation geomorphology and dynamics. Geomorphology 48, 245-268. https://doi.org/10.1016/S0169-555X(02)00184-8.

Hugenholtz, C.H., Levin, N., Barchyn, T.E., Baddock, M.C., 2012. Remote sensing and spatial analysis of aeolian sand dunes: a review and outlook. Earth Sci. Rev. 111, 319-334. https://doi.org/10.1016/j.earscirev.2011.11.006.

Hunt, J.C.R., 1971. The effect of single buildings and structures. Philos. Trans. R. Soc London. Ser. A, Math. Phys. Sci. 269, 457-467. https://doi.org/10.1098/ rsta.1971.0044.

Instituto Tecnológico Geominero de España, 1990. Mapa geológico de España escala, 1, 25.

Jackson, N.L., Nordstrom, K.F., 2011. Aeolian sediment transport and landforms in managed coastal systems: a review. Aeolian Res. 3, 181-196. https://doi.org/ 10.1016/j.aeolia.2011.03.011.

Leatherman, S.P., 1976. Barrier island dynamics: overwash processes and aeolian transport. In: Proc. 15th Coastal Engr. Conf. ASCE, New York, pp. 1958-1974.

Lithgow, D., Martínez, M.L., Gallego-Fernández, J.B., 2015. The "ReDune" index (Restoration of coastal Dunes Index) to assess the need and viability of coastal dune restoration. Ecol. Indica 49, 178-187. https://doi.org/10.1016/j. ecolind.2014.10.017.

Livingstone, I., Wiggs, G.F.S., Weaver, C.M., 2007. Geomorphology of desert sand dunes: a review of recent progress. Earth Sci. Rev. 80, 239-257. https://doi.org/10.1016/j. earscirev. 2006.09.004.

Lozato-Giotart, J.P., Insa, J.S., 1990. Geografía del turismo: del espacio contemplado al espacio consumido. Masson, Madrid.

Marrero-Rodríguez, N., García-Romero, L., Sánchez-García, M.J., HernándezCalvento, L., Pérez-Chacón Espino, E., 2020. An historical ecological assessment of land-use evolution and observed landscape change in an arid aeolian sedimentary system. Sci. Total Environ. 716, 137087. https://doi.org/10.1016/j. scitotenv.2020.137087.

Martínez, J., 1990. La provincia morfodinámica de Morro Besudo- Faro de Maspalomas (Isla de Gran Canaria, España): conocimiento y comprensión de sus procesos geomorfológicos y sedimentarios para la planificación y gestión de este litoral., I Reunión Nacional de Geomorfología.

Martínez, M.L., Hesp, P.A., Gallego-Fernández, J.B., 2013. Coastal dunes: human impact and need for restoration. In: Martinez, M.L., Gallego-Fernandez, J.B., Hesp, P.A. (Eds.), Restoration of Coastal Dunes. Chapter, vol. 1, pp. 1-14.

Máyer Suárez, P., Pérez-Chacón Espino, E., Cruz-Avero, N., Hernández-Calvento, L., 2012. Características del viento en el campo de dunas de Maspalomas (Gran Canaria, islas Canarias, España). Nimbus 381-397.

Ministerio de Medio, Ambiente, 2007. Estudio integral de la playa y dunas de Maspalomas (Gran Canaria). Madrid (Spain).

Ministerio de Medio Ambiente y Medio Rural y Marino, 2008. Plan nacional de Adaptación al Cambio climático. Madrid.

Mir-Gual, M., Pons, G.X., Martín-Prieto, J.Á., Roig-Munar, F.X., Rodríguez-Perea, A. 2013. Geomorphological and ecological features of blowouts in a western Mediterranean coastal dune complex: a case study of the Es Comú de Muro beachdune system on the island of Mallorca. Spain. Geo Mar. Lett. 33 (2-3), 129-141. https://doi.org/10.1007/s00367-012-0298-7.

Miththapala, S., 2008. Seagrasses and sand dunes. IUCN.

Morton, R.A., Paine, J.G., Gibeaut, J.C., 1994. Stages and durations of post-storm beach recovery, southeastern Texas Coast, USA. J. Coast Res. 10, 884-908.

Nazarnia, H., Nazarnia, M., Sarmasti, H., Wills, W.O., 2020. A systematic review of civil and environmental infrastructures for coastal adaptation to sea level rise. Civ. Eng. J. 6, 1375-1399. https://doi.org/10.28991/cej-2020-03091555.

Nordstrom, K.F., 2000. Beaches and Dunes of Developed Coasts, Beaches and Dunes of Developed Coasts. Cambridge University Press. https://doi.org/10.1017/ CBO9780511549519.

Nordstrom, K.F., Lampe, R., Vandemark, L.M., 2000. Reestablishing naturally functioning dunes on developed coasts. Environ. Times 25 (1), 37-51. https://doi. org/10.1007/s002679910004. Manage.

Nordstrom, K.F., Jackson, N.L., Hartman, J.M., Wong, M., 2007. Aeolian sediment transport on a human-altered foredune. Earth Surf. Process. Landforms 32 (1), $102-115$.

Paskoff, R., 1993. Côtes en danger. Practiques de la Géographie. Masson, Paris.

Peña-Alonso, C., 2015. Diseño y aplicación de indicadores de vulnerabilidad y calidad para playas y dunas de Canarias: una propuesta metodológica. PhD Thesis. Universidad de Las Palmas de Gran Canaria.

Peña-Alonso, C., Gallego-Fernández, J.B., Hernández-Calvento, L., HernándezCordero, A.I., Ariza, E., 2018. Assessing the geomorphological vulnerability of arid beach-dune systems. Sci. Total Environ. 635, 512-525. https://doi.org/10.1016/j. scitotenv.2018.04.095. 
Pérez-Chacón, E., Hernández-Calvento, L., Hernández-Cordero, A.I., Máyer Suárez, P., Romero, L.E., Alonso, I., Mangas, J., Menéndez, I., Sánchez, I., Ojeda, J., Ruiz, P., Alcántara, J., 2007. Maspalomas: claves científicas para el análisis de su problemática ambiental. Universidad de Las Palmas de Gran Canaria.

Peterka, J.A., Meroney, R.N., Kothari, K.M., 1985. Wind flow patterns about buildings. J. Wind Eng. Ind. Aerod. 21, 21-38. https://doi.org/10.1016/0167-6105(85)90031 5.

Poppema, D.W., Wijnberg, K.M., Mulder, J.P.M., Hulscher, S.J.M.H., 2019. Scale experiments on aeolian deposition and erosion patterns created by buildings on the beach. In: Sediments, Coastal (Ed.), World Scientific Pub Co Pte Lt, pp. 1693-1707. https://doi.org/10.1142/9789811204487_0146.

Robinson, A.H., Sale, R.D., Morrison, J.L., Muehrcke, P.C., 1987. Elementos de Cartografía. Omega, Barcelona.

Santana-Cordero, A.M., Monteiro Quintana, M.L., Hernández-Calvento, L., 2014. Reconstructing the environmental conditions of extinct coastal dune systems using historical sources: the case of the Guanarteme dune field (Canary Islands, Spain). J. Coast Conserv. 18 https://doi.org/10.1007/s11852-014-0320-5.

Santana-Cordero, A.M., Monteiro Quintana, M.L., Hernández-Calvento, L., Pérez-Chacón Espino, E., García-Romero, L., 2016. Long-term human impacts on the coast of La graciosa, canary islands. Land Degrad. Dev. 27, 479-489. https://doi.org/10.1002/ ldr.2369.
Saunders, K.E., Davidson-Arnott, R.G.D., 1990. Coastal dune response to natural disturbances. Proc. Symposium on Coastal Sand Dunes. NRC, Ottawa 321-345.

Smith, A.B., Jackson, D.W.T., Cooper, J.A.G., Hernández-Calvento, L., 2017. Quantifying the role of urbanization on airflow perturbations and dunefield evolution. Earth's Futur 5, 520-539. https://doi.org/10.1002/2016EF000524.

Soneiro-Callizo, J., 1991. Aproximación a la geografía del turismo, academia.edu. Síntesis, Madrid.

Suárez Rodríguez, C., Hernández-Calvento, L., 1998. Impactos ambientales provocados por los equipamientos turísticos en los ecosistemas dunares. Rev. Medio Ambient 7 , $16-18$.

Vera Rebollo, J.F., 1997. Análisis territorial del turismo ;: una nueva geografía del turismo. Ariel, Madrid.

Viera-Pérez, M., 2015. Estudio detallado de la duna costera de Maspalomas (Gran Canaria, Islas Canarias): interacción "Traganum moquinii" - dinámica sedimentaria eólica en un entorno intervenido. Recomendaciones de cara a su gestión. PhD Thesis, Universidad de Las Palmas de Gran Canaria.

Viera-Pérez, M., Hernández-Calvento, L., Hesp, P.A., Santana-del Pino, A., 2019. Effects of artificial light on flowering of foredune vegetation. Ecology 100, 1-10. https:// doi.org/10.1002/ecy.2678. 